Syntax Literate: Jurnal Ilmiah Indonesia p-ISSN: 2541-0849 e-ISSN: 2548-1398

Vol. 7, Special Issue No. 1, Januari 2022

\title{
PERKEMBANGAN EMOSI PESERTA DIDIK
}

\section{Abdul Basit, Septi Gumiandari}

Prodi Pendidikan Agama Islam, Program Pascasarjana IAIN Syekh Nurjati Cirebon

Email: abdulbasit110596@gmail.com, septigumiandari@gmail.com

\begin{abstract}
Abstrak
Penelitian ini bertujuan untuk mengetahui perkembangan emosi anak peserta didik. Jenis penelitian yang digunaka yaitu studi kepustakaan dengan pendekatan penelitian kualitatif. Teknik pengumpulan data yaitu dengan studi dokumentasi yang dilakukan dengan menganalisis isi dokumen yang berhubungan dengan masalah yang diteliti. Sumber data dalam penelitian ini yaitu buku dan jurnal yang relevan dengan kajian. Temuan dalam penelitian ini menunjukkan bahwa perkembangan anak yang pesat pada usia Sekolah Dasar yaitu perkembangan emosi. Perkembangan tersebut tidaklah sama antara satu anak dengan yang lainnya. Banyak faktor yang dapat mempengaruhi perkembangan tersebut diantaranya faktor lingkungan keluarga dan lingkungan sekolah. Sedangkan perkembangan emosi manusia dalam Islam termuat dalam 3 bentuk ikatan, yaitu: ikatan emosional pada bayi, ikatan emosional pada pasangan dan ikatan emosional orag tua. Perkembangan emosi moder hanya melihat bahwa manusia sebagai manusia yang materialsistis, dan tidak diaggap penting dalam perkembangan spiritualistisnya. Tetapi berbeda dengan Islam yang memang manusia sebagai hamba Allah yang juga emosi spitualnya sangat dianggap penting, sekaligus materi sebagai penunjang dari luarnya sebagai implikasi dari spiritualnya. Di mana emosi yang mulai darimayi, ia mengenal lingkungan dan lainya sampai usia lanjut ia bisa mengontrol emosionalnya dengan baik dari luar mapun dalam (materi atau spiritualnya).
\end{abstract}

Kata Kunci: perkembangan emosi; lingkungan; spiritual.

\section{Abstract}

This study aims to determine the emotional development of students. The type of research used is a literature study with a qualitative research approach. The data collection technique is the documentation study carried out by analyzing the contents of the documents related to the problem under study. Sources of data in this study are books and journals relevant to the study. The findings in this study indicate that the rapid development of children at elementary school age is emotional development. This development is not the same from one child to another. Many factors influencing this development include family, environmental, and school environments. At the same time, the story of human emotions in Islam is contained in 3 forms of bonds, namely: emotional bonds in infants, emotional bonds in partners, and emotional bonds with parents. Modern emotional development only sees humans as materialistic humans and is not considered necessary in their spiritual growth. However, it is different from Islam, which is

$\begin{array}{ll}\text { How to cite: } & \text { Basit, A. \& Gumiandari, S. (2022) Perkembangan Emosi Peserta Didik, Syntax Literate: Jurnal Ilmiah } \\ & \text { Indonesia, 7(1). } \\ \text { E-ISSN: } & 2548-1398 \\ \text { Published by: } & \text { Ridwan Institute }\end{array}$


indeed human as a servant of Allah, whose spiritual emotions are also essential and material support from the outside as a spiritual implication. Where feelings start from a young person, he knows the environment and others until he is old he can control his emotions well both from outside and inside (material or spiritual)

Keywords: emotional development; environment; Spiritual

\section{Pendahuluan}

Anak adalah generasi yang akan meneruskan kehidupan bangsa yang akan berlangsung secara terus menurus dan bersifat alamiah. Pada generasi tersebut anak akan tumbuh dan berkembang sesuai dengan tahap pertumbahan dan perkembangannya masingmasing (Jenggawah et al., 2010). Perkembangan pada hakikatnya merupakan suatu perubahan yang berkesinambungan dan progresif yang berasal dari dalam dalam diri anak dari ia mulai berada di dunia sampai meninggal. Hurlock menyebutkan perkembangan pada dasarnya adalah serangkaian bentuk perubahan yang progresif yang terjadi sebagai akibat dari proses kematangan dan pengalaman (DA, 2021).

Perkembangan anak akan berlangsung secara optimal jika berkembangnya sesuai dengan fase dan tugas perkembangannya masing-masing. Anak usia 6 sampai dengan 12 tahun dalam kategori usia Sekolah Dasar. Pada usia ini, anak mengalami perkembangan yang sangat pesat. Perkembangan anak juga memiliki pola-pola tersendiri yang khas sesuai dengan aspek perkembangan. Beberapa aspek yang berkembang pesat pada usia SD yaitu perkembangan emosi anak.

Psikologi merupakan ilmu yang membahas tentang gejala-gejala kemanusiaan, dengan tujuan saling mengetahui, memahami dan menyadari apa yang harus dilakukan untuk perubahan perubahan tingkah tingkah laku, ilmu yang mempelajari mempelajari tentang tentang tingkah tingkah laku manusia manusia dalam berinteraksi dengan lingkungannya (Vol et al., 2020).

Disamping itu, hal yang lebih penting untuk diketahui adalah apa yang mereka rasakan. Dengan demikian, semakin banyak memahami dunia anak dan remaja seperti apa yang mereka alami, semakin perlu melihat kedalam kehidupan emosionalnya dan memahami perasaan-perasaannya, baik perasaan tentang dirinya sendiri maupun orang lain (Vol et al., 2020).

Menginjak usia sekolah, anak-anak mulai menyadari bahwa pengungkapan emosi secara kasar tidaklah diterima dimasyarakat. Emosi merupakan faktor dominan yang mempengaruhi tingkah laku individu, dalam hal ini termasuk pula prilaku belajar. Menurut Daniel Goleman menyataka menyatakan bahwa unsur emosi merupakan faktor yang turut berperan dalam keberhasilan hidup seseorang. Aspek emosi mengalami perkembangan yang signifikan pada periode anak. Seiring pertambahan usia, kemampuan kemampuan anak mengendalikan mengendalikan emosinya emosinya sendiri semakin berkembang. Anak-anak semakin menyadari tentang perasaannya sendiri dan orang lain. Anak-anak juga semakin mampu mengatur ekspresi emosi dan 
situasi sosial dan mampu mereaksi kondisi stres yang dialami orang lain (Tusyana et al., 2019).

Kajian tentang perkembangan emosi bayi dan anak-anak dalam bidang psikologi masih relative baru. Penelitian empirik di bidang ini baru dilakukan beberapa puluh tahun yang lalu. Pada awal tahun 1980-an Caroll Izard dan kawan-kawannya mempublikasikan penelitiannya tentang ekspresi emosi pada bayi. Peneliti kemudian mencoba melakukan berbagai pendekatan di bidang ini dari berbagai perspektif, termasuk konstruksionis sosial, teori emosi diferensial, dan teori sosial belajar. Masingmasing pendekatan ini mengeksplorasi cara bayi dan anak berkembang secara emosional, dengan perdebatan apakah emosi dipelajari atau ditentukan sebelumnya secara biologis, atau apakah anak dapat melakukan manajemen terhadap pengalaman dan perilaku emosionalnya (Sumiati et al., 2021).

Emosi merupakan perasaan intens yang ditunjukkan oleh seseorang atas suatu kejadian atau peristiwa (Zainab, 2020). Perkembangan emosi menjadi sebuah krisis dalam perkembangan anak. Dimana, emosi merupakan faktor yang dominan dalam mempengaruhi tingkah laku individu, dalam hal ini termasuk pula perilaku belajar.

American Academy of Pediatrics menyatakan bahwa perkembangan emosi mengacu pada kemampuan anak untuk memiliki pengetahuan dalam mengelola dan mengekspresikan emosi dengan baik seperti ungkapan emosi positif maupun emosi negatif, anak mampu menjalin hubungan dengan anakanak lain dan orang dewasa (Tusyana et al., 2019).

\section{Metode Penelitian}

Jenis penelitian yang digunakan dalam penelitian ini adalah studi kepustakaan (Library Research) dengan pendekatan penelitian kualitatif. Studi kepustakaan merupakan suatu studi yang digunakan untuk mengumpulkan informasi atau pengumpulan data pustaka dengan cara menelaah, membaca, dan mencatat serta mengolah bahan penelitian. Data pustaka pada umumnya adalah data sekunder atau pendukung sehingga peneliti mendapatkan data bukan dari data orisinil atau tangan pertama di lapangan, tetapi diperoleh dari tangan kedua. Selain itu, kondisi dari data kepustakaan ini tidak dibatasi oleh ruang dan waktu (Sumiati et al., 2021).

Teknik pengumpulan data dalam penelitian ini adalah studi dokumentasi, yaitu teknik pengumpulan data dengan cara menganalisi isi dokumen yang berkaitan dengan masalah yang diteliti. Menurut Gunawan, analisis dilakukan dengan cara membandingkan dan memadukan dokumendokumen untuk membentuk suatu hasil kajian yang sistematis (Lestari et al., 2019). Sumber data yang digunakan yaitu berupa buku dan jurnal yang terkait dengan topik yang dipilih.

Analisis data yang digunakan dalam penelitian ini yaitu analisis konten (content analysis), karena dalam penelitian ini akan menganalisis beberapa teori mengenai perkembangan bahasa, emosi, dan sosial anak SD. Menurut Weber "analisis konten merupakan suatu penelitian yang menggunakan sekumpulan prosedur untuk mendapatkan kesimpulan yang sahih dari sebuah buku atau dokumen”. 


\section{Hasil Dan Pembahasan}

\section{Perkembangan Emosi Anak}

Menurut pendapat (Magdalena et al., 2020) usia sekolah dasar adalah anak yang berusia sekitar 6-12 tahun, yang mana pada masa usia sekolah tersebut memiliki perkembangan emosi yang berbeda yaitu sebagai berikut :

a. Anak usia 5-6 sudah mengenal dan mengetahui aturan yang berlaku. Anak sudah mengetahui konsep adil dan rahasia. Ini merupakan bentuk keterampilan pada anak untuk dapat menyembukan informasi.

b. Pada usia 7-8 tahun anak sudah mengerti akan rasa malu dan bangga terhadap sesuatu. Anak dapat mengungkapkan emosi yang dirasakannya. Semakin bertambah usia anak semakin anak dapat memahami perasaan orang lain.

c. Pada usia 9-10 tahun anak sudah dapat menyembunyikan dan mengungkapkan emosinya dan sudah dapat merespon emosi orang lain. Anak juga bisa mengontrol emosi negatifnya. Anak mengetahui apa saja yang membuat dirinya merasa sedih, takut dan marah sehingga anak mampu beradaptasi dengan emosinya

d. Ada pada usia 11-12 tahun, anak sudah mengetahui tentang baik buruk, nilainilai, dan norma-norma yang berlaku pada masyarakat serta adanya perkembangan yang meningkat tidak sekaku saat di usia kanak-kanak awal. Anak sudah mengetahui bahwa adanya perubahan pada nilai-nilai, norma-norma dan prilaku serta anak. Perikaku anak juga semakin beragam.

Ciri-ciri emosi pada anak menurut (Ngura et al., 2020) adalah sebagai berikut.

a. Emosi yang terjadi pada anak biasanya relatif relatif lebih singkat (sebentar) dan mudah berubah. Hal ini dikarenakan emosi pada anak biasanya diungkapkan dalam bentuk tindakan, berbeda dengan orang dewasa yang emosinya relatif lebih lama. Emosi yang sering dimunculkan oleh anak seperti kesedihan, kemurungan, kebahagiaan, humor, dan lain sebagainya.

b. Emosi pada anak relatif lebih kuat dan hebat. Hal ini terihat ketika anak sedang sedih, marah dan takut. Anak terlihat marah sekali ketika terdapat hal yang tidak disukainya, dan anak akan menangis jika ada sesuatu yang membuatnya sedih, dan anak akan tertawa terbahak-bahak ketika ada sesuatu yang membuatnya lucu namun emosi tersebut akan cepat hilang. Namun berbeda dengan orang dewasa yang tidak terlalu menampakkan emosi tersebut.

c. Emosi anak mudah berubah. Hal ini terlihat ketika kita menjumpai anak yang sedang menangis, ia akan menangis dengan tersedu-sedu namun emosi tersebut hanya sebentar dia akan tertawa kembali ketika ada sesuatu yang lucu.

d. Emosi anak nampak berulang-ulang. Hal ini timbul karena anak dalam proses perkembangan kearah kedewasaan. Ia harus mengadakan penyesuaian terhadap situasi di luar, dan hal ini dilakukan secara berulang-ulang

e. Respon emosi pada anak berbeda-beda. Pengamatan membuktikan bahwa pada waktu bayi lahir, pola responnya relatif sama. Namun, secara perlahan-lahan 
berubah, pengalaman belajar dari lingkungannya membuat perbedaan tingkah laku sebagai bentuk variasi emosi pada anak.

f. Emosi anak dapat dilihat atau diketahui dari tingkah laku yang ditunjukkan anak. Meskipun kadang kala anak tidak menunjuukkan emosinya secara langsung, namun emosi itu dapat diketahui dari tingkah lakunya, seperti menangis, melamun, menghisap jari, gelisah, dan lain sebagainya.

g. Adanya perubahan emosi dalam kekuatannya. Seperti kita menjumpai ada anak yang memiliki emosi itu yang begitu kuat, kemudian berkurang. Emosi yang pada mulanya lemah menjadi lebih kuat. seperti: seorang anak menunjukkan rasa malu-malu ketika berjumpa orang asing atau berda ditempat orang lain. Kemudian ketika ia merasa sudah merasa akrab dan dekat dia tidak akan menunjukkan rasa malu-malunya lagi.

h. Adanya perubahan-perubahan bentuk ungkapan emosional anak. Anak-anak akan menunjukkan keinginan yang begitu kuat pada apa yang ia hendakki. Ia tidak memperhitungkan apakah hal itu baik atau buruk untuk dirinya, juga tidak mempertimbangkan bahwa yang ia kehendaki itu dapat dipenuhi oleh orang tuanya atau tidak yang penting ia menginginkannya.

Perkembangan emosi anak berkaitan dengan reaksi anak terhadap berbagai perasaan berbeda yang mereka alami. Perkembangan emosi ini nantinya akan berpengaruh terhadap bagaimana sikap dan cara anak dalam mengambil keputusan dan bagaimana cara anak menikmati kehidupannya.

Perkembangan emosi anak akan sejalan dengan tahap-tahap perkembangan anak terutama pada masa SD yang perkembangannya akan semakin kompleks tergantung dengan pengalaman apa yang telah di dapatkannya. Perkembangan emosi anak juga akan berpengaruh terhadap mental anak sehingga perkembangan anak dangat perlu diperhatikan agar tidak ada pengaruh negatif yang akan berdampak pada mental anak (Talango, 2012).

\section{Perkembangan dan pertumbuhan Emosi Manusia dalam prespektif Islam}

Dalam islam segala macam emsosi dan ekspresianya Allah ciptakan untuk bisa merubah dan membentuk manusia menjadi manusia yang lebih sempurna (Nurjan, 2010). Dalam Al-qur'an telah menyebutkan perkembangan emosi dalam 3 ikatan yaitu: ikatan emosional yang penting, yaitu ikatan emosi yaitu ikatan emosional pada bayi, ikatan emosional terhadap pasangan dan ikatan emosional orang tua.

a. Ikatan emosional pada bayi Ikatan emosional orang tua dengan bayinya bersifat timbal balik. Orang tua siap untuk menjalin ikatan emosional ini ketika mengandung bayinya, dan apapun yang berkaitan dengan bayinya nanti. Berbagai stimulasi yang diberikan oleh orang tua kepada bayi mereka menentukan kualitas ikatan emosional ini. Dalam Penelitian (Yusra et al., 2020) dan Al-Qur'an menggambarkan pentingnya hubungan ibu dan anak pada tahun-tahun pertama kelahiranya, terutama melalui pemberian air susu ibu.31 Seperti dalam surat luqman ayat 14 yang artinya "Dan Kami 
perintahkan kepada manusia (berbuat baik) kepada dua orang ibubapaknya; ibunya telah mengandungnya dalam keadaan lemah yang bertambahtambah, dan menyapihnya dalam dua tahun. tambah, dan menyapihnya dalam dua tahun. Bersyukurl Bersyukurlah kepada-Ku dan kepada ah kepada-Ku dan kepada dua orang ibu bapakmu, hanya kepada-Kulah kembalimu." Dan surat al-ahqaf ayat 15 yang artinya "ibunya mengandun ibunya mengandungnya dengan gnya dengan susah payah, dan susah payah, dan melahirkannya dengan susah payah rkannya dengan susah payah (pula). Mengandungnya sampai menyapihnya adalah tiga puluh bulan"

Bayi yang kurang mengalami perhatian sosial atau bahakan mengalami kekerasan dari figur ibu ataupun ayah, dapat berkembang menjadi orang yang menyendiri dan apatis (Kusuma \& Sutapa, 2020). Bahkan bayi dapat mengalami kekurangan perkembangan intlektual, masalh prilaku dan gangguan ikatan reaktif.

Ikatan emosional bayi Ikatan emosional bayi berkembang sesuai dengan berkembang sesuai dengan usianya. Yaitu:

$>6$ minggu : masih belum menunjukan minat sosialnya.

$>$ 6-7 bulan : lebih menyukaistimulus sosial

$>$ 7-9 bulan : menunjukan berat jika berpisah dengan orang dewasa.

$>$ 8-10 bulan : menunjukan reaksi menghindar, dan ter, dan tertarik jika bertemu dengan orang asing., cemas berpisah dengan ibunya.

b. Ikatan emosional terhadap pasangan ikatan emosional terhadap pasangan Ikatan emosi yang penting dalam kehidupan seseorang yang menginjak dewasa adalah ikatan emsosi terhadap pasangan hidupnya. Salah satu bentuknya yitu terbentuknya ikatan pernikahan sepsang suami dan istri (Subarkah, 2019). Seperti dalam surat ar-Rum ayat 21 yang artinya "Dan di antara tanda-tanda kekuasaan-Nya ialah Dia menciptakan untukmu isteri-isteri dari jenismu sendiri, supaya kamu cenderung dan merasa tenteram kepadanya, dan dijadikan-Nya diantaramu rasa kasih dan sayang. Sesungguhnya pada yang demikian itu benar-benar terdapat tanda-tanda bagi kaum yang berfikir."

c. Ikatan emosional orang tua

pada saat memasuki memasuki usia tua, seseorang seseorang mulai mengalami mengalami kemunduran kemunduran fisik (Asih, 2018). Islam mewajibkan anak untuk memelihara orang tua, sebagai balasan apa yang dilakukan orang tua sewaktu masih kecil. Seperti tercantum dalam surat luqman ayat 14 yang artinya "Dan Kami perintahkan kepada manusia (berbuat baik) kepada dua orang ibubapaknya; ibunya telah mengandungnya dalam keadaan lemah yang bertambah-tambah, dan menyapihnya dalam dua tahun. Bersyukurlah kepada-Ku dan kepada dua orang ibu bapakmu, hanya kepadaKulah kembalimu." 


\section{Ekspresi dan Persepsi Emosi}

Darwin mengatakan bahwa ekspresi emosi manusia tidaklah bersifat unik tetapi dapat pula ditemukan pada banyak jenis yaitu binatang. Banyak dari peristiwa sosial dialami oleh manusia menghasilkan emosi yang sama juga dialami oleh binatang. Pendapat Darwin ini merupakan hasil dari ekspresimen berkesinambungan yang dilakukan merujuk pada teori evolusinernya. Sebagai salah satu ilmuwan yang pertama kali menggunakan foto sebagai ilustrasi dan menggunakan metode judgemen untuk mempelajari nilai isyarat dari suatu ekspresi yang sekarang menjadi ekspresi paling sering dibahas dengan menggunakan metode psikologis (Nadhiroh, 2015).

Al Baqi (2015) juga berpendapat bahwa bentuk-bentuk ekspresi emosi manusia yang muncul dalam realitas pada umumnya ditampilkan melalui: (a) ekspresi wajah, (b) ekspresi suara, (c) ekspresi sikap dan tingkah laku dan (d) ekspresi lainnya.

Bentuk-bentuk ekspresi emosi manusia yang sering muncul dalam realitas: ekspresi wajah, suara, sikap dan tingkah laku, serta ekspresi lain seperti pingsan, kejang-kejang, ngompol dan sebagainya.

1. Ekspresi wajah

Ekspresi wajah merupakan ekspresi paling umum terjadi manakala seseorang mengalami peristiwa emosi. Wajah pucat, merah, mengerut, berseriseri adalah sederet bentuk ekspresi emosi yang lazim dialami. Bukan mustahil ekspresi wajah bersifat hereditas, karena fakta membuktikan bahwa bayi yang terlahir buta-tuli sekalipun mampu mengomunikasikan emosi dengan ekspresiekspresi yang khas manusia normal. Jadi, pengalaman hanyalah memperkaya ekspresi wajah.

2. Ekspresi suara

Ekspresi suara saat emosi dikenal secara umum dalam pergaulan seharihari, seperi tertawa, bersenandung, berteriak-teriak, memaki, atau tiba-tiba terenyak dengan tatapan kosong. Ekspresi suara mungkin tidak segampang diketahui bila dibandingkan dengan ekspresi wajah dalam mengomunikasikan emosi, tapi keduanya sangat penting. Para pakar komunikasi menganggap komunikasi dalam bentuk ekspresi suara lebih mudah dipahami dan lebih berpengaruh ketimbang berbentuk tulisan. Aksentuasi dalam percakapan sangat membantu memahami makna yang dimaksud oleh pembicara.

\section{Ekspresi sikap dan tingkah laku}

Ekspresi emosi dalam bentuk tingkah laku cakupannya sangat luas, seluas aktivitas manusia itu sendiri. Namun, dapat dibagi menjadi dua ekspresi sikap dan tingkah laku yakni: tingkah laku pelibatan diri (attachment) dan pelepasan diri (withdrawal). Tingkah laku emosi dengan pelibatan diri adalah tingkah laku dengan upaya bergerak maju mempertahankan suasana yang menyenangkan pada emosi positif. Tingkah laku agresif dan eksplosif adalah contoh pelibatan diri dalam menghadapi berbagai ancaman sebagai upaya 
mekanisme pertahanan diri (self-defense mechanism). Sedangkan tingkah laku emosi dalam bentuk pelepasan diri adalah lari atau menghindar dari obyek yang menimbulkan emosi. contoh dari ekspresi pelepasan diri adalah, lari terbirit-birit untuk menyelamatkan diri dari sumber yang menakutkan atau tertunduk malu.

4. Ekspresi lain-lain

Pada kasus-kasus emosi berat dijumpai pula adanya orang yang mengalami syok berat atau bahkan tak sadarkan diri (pingsan). Demikian juga pada sebagian orang, ada yang latah dengan menyebut kata-kata tertentu, terutama ketika kaget. Latah ini banyak terjadi dikalangan masyarakat Indonesia dan ditengarai tidak dikenal di dunia barat, sehingga istilah itu telah menjadi istilah ilmiah. Latah ini dapat digolongkan pada ekpresi suara tetapi karena ekspresinya spesifik dan tidak terjadi pada setiap orang, maka dimasukkan dalam kelompok ekspresi lain-lain (Nadhiroh, 2015).

\section{Kesimpulan}

Perkembangan sebagai rangkaian perubahan progesif yang terjadi sebagai akibat akibat dari proses kematangan dan pengalaman. Sedangkan emosi sebagai suatu keadaan yang terangsang dari organisme mencakup perubahan-perubahan yang disadari, memiliki sifat yang mendalam, dan menyebabkan perubahan perilaku. Sangat banyak pendapat yang memberikan pandangan terhadap macam-macam dari emosi, yaitu: Berdasarkan kajian psikologis, emosi atas dasar arah aktifitasnya, yaitu: Marah, Takut, Cinta, dan Depresi. Ada juga Emosi sensoris dan psikis.

Sedangkan perkembangan emosional dalam sudut pandang Islami yaitu tergolong dalam 3 ikatan yakni, ikatan perkembangan pada bayi, pada pasangan, dan pada orang tua. Masa bayi sebagai masa awal terpenting dalam tahapan perkembangan emosional, yang mana dibentuk oleh orang tua dan lingkungan sekitarnya. Analis Analisis yang ditemukan oleh penulis bahwa pendapat yang ditemukan oleh Alia pendapat yang ditemukan oleh Aliah Purwakania Hasan inkonsistensi dalam menjelaskan perkembangan emosi modern dan Islam. Yang mana perkembangan emosi modern lebih rinci dibandingkan dengan Islam. Ia juga tidak menyebutkan masa remaja dan juga di usia lanjut dalam pandangan Islamnya.

Setiap anak memiliki tugas dan tahap perkembangan yang berbeda-beda pula sesuai dengan aspek-aspek perkembangannya. Beberapa aspek perkembangan yang berkembang pesat pada usia Sekolah Dasar adalah perkembangan emosi anak. Bahasa merupakan media komunikasi yang digunakan untuk menyampaikan pesan (pendapat dan perasaan) dengan menggunakan simbol-simbol yang telah disetujui bersama, kemudian kata dirangkai berdasarkan urutan membentuk kalimat yang bermakna, dan mengikuti aturan atau tata bahasa yang berlaku dalam suatu komunitas atau masyarakat.

Perkembangan emosi juga sangat penting dalam perkembangan anak dimana emosi merupakan faktor sangat menonjol yang mempengaruhi tingkah laku individu, dalam hal ini termasuk pula perilaku belajar. Perkembangan emosi ini akan sejalan 
Abdul Basit, Septi Gumiandari

dengan perkembangan sosial anak dimana perkembangan sosial disebut sebagai pencapaian kematangan dalam hubungan sosial dan proses belajar untuk menyesuaikan diri dengan norma-norma kelompok tradisi dan moral. 


\section{BIBLIOGRAFI}

Asih, T. (2018). Perkembangan Tingkat Kognitif Peserta Didik Di Kota Metro. Didaktika Biologi: Jurnal Penelitian Pendidikan Biologi, 2(1), 9-17. Google Scholar

DA, F. (2021). Analisis Hasil Belajar Matematika Ditinjau Dari Kecerdasan Emosional Peserta Didik Kelas V Sdn 204 Palembang. Indiktika: Jurnal Inovasi Pendidikan Matematika, 3(1), 104. Google Scholar

Idrus, S. F. I. Al, Damayanti, I. P. S., \& Ermayani. (2020). Pengembangan Kecerdasan Emosional Peserta Didik Di Sekolah Dasar Melalui Pendidikan Karakter. PENDASI: Jurnal Pendidikan Dasar Indonesia, 4(1), 137-146. Google Scholar

Jenggawah, N., Pada, S., Berpikir, K., Dan, K., \& Belajar, M. (2010). Digital Digital Repository Repository Universitas Universitas Jember Jember Digital Jember Digital Repository Repository Universitas Universitas Jember. Google Scholar

Kusuma, W. S., \& Sutapa, P. (2020). Dampak Pembelajaran Daring terhadap Perilaku Sosial Emosional Anak. Jurnal Obsesi : Jurnal Pendidikan Anak Usia Dini, 5(2), 1635-1643. Google Scholar

Lestari, D. P., Sofah, R., \& Putri, R. M. (2019). Tingkat Kecerdasan Emosi Peserta Didik Kelas Xi Di Sma Negeri 15 Palembang. Jurnal Konseling Komprehensif: Kajian Teori Dan Praktik Bimbingan Dan Konseling, 6(1), 11-20. Google Scholar

Magdalena, I., Destiana, D., \& Yuniawan, N. (2020). Perbedaan Individu Peserta Didik Sekolah Dasar. Bintang: Jurnal Pendidikan Dan Sains, 2(3), 255-268. Google Scholar

Ngura, E. T., Go, B., \& Rewo, J. M. (2020). Pengaruh Media Pembelajaran Buku Cerita Bergambar Terhadap Perkembangan Emosional Anak Usia Dini. Jurnal Ilmiah Pendidikan Citra Bakti, 7(2), 118-124. Google Scholar

Ninla Elmawati Falabiba, Anggaran, W., Mayssara A. Abo Hassanin Supervised, A., Wiyono, B. ., Ninla Elmawati Falabiba, Zhang, Y. J., Li, Y., \& Chen, X. (2014). 済無No Title No Title No Title. Paper Knowledge . Toward a Media History of Documents, 5(2), 40-51.

Nurjan, S. (2010). Perkembangan Peserta Didik Perspektif Islam. In Titah Surga. Google Scholar

Subarkah, M. A. (2019). Pengaruh Gadget Terhadap Perkembangan Anak. Rausyan Fikr : Jurnal Pemikiran Dan Pencerahan, 15(1), 1689-1695. Google Scholar

Sumiati, Sobari, T., \& Fatimah, S. (2021). Hubungan keputusan karier dengan kematangan emosi peserta didik kelas ix smpn 1 garut 1. Fokus, 4(1), 13-24. Google Scholar 
Abdul Basit, Septi Gumiandari

Talango, S. R. (2012). John W. Santrock. Life-Span Development, Perkembangan Masa Hidup Edisi Ketigabelas , (Jakarta: Erlangga PT. Gelora Aksara Pratama, 2012)., h.7. 92-106. Google Scholar

Tusyana, E., Trengginas, R., \& . S. (2019). Analisis Perkembangan Sosial-Emosional Tercapai Siswa Usia Dasar. Inventa, 3(1), 18-26. Google Scholar

Vol, J. A., Usia, A., Di, R., \& Kediri, M. (2020). Jurnal Al-Makrifat Vol 5, No 1, April 2020.96-107.

Yusra, Dewi, Y., \& Qadri, M. (2020). Jurnal Buah Hati. Jurnal Buah Hati, 7(2), 125137.

Zainab, K. S. (2020). Desain Program Pembelajaran Perspektif Keberagamaan Peserta Didik Sekolah Menengah Atas. Attractive: Innovative Education Journal, 2(2), Google Scholar

\section{Copyright holder:}

Abdul Basit, Septi Gumiandari (2022)

First publication right:

Syntax Literate: Jurnal Ilmiah Indonesia

This article is licensed under:

$$
\text { (c) }
$$

